\title{
Influence of Soil Type on Root Development and above-and below-Ground Biomass of 1-3 year-old Populus deltoides $\times$ nigra Grown from Poles
}

\author{
Ian McIvor ${ }^{1 *}$, Mike Marden², Grant Douglas ${ }^{3}$, Duncan Hedderley ${ }^{1}$ and Chris Phillips ${ }^{4}$ \\ ${ }^{1}$ Plant \& Food Research, New Zealand \\ ${ }^{2} 31$ Haronga Rd, New Zealand \\ ${ }^{3}$ GBD Science, New Zealand \\ ${ }^{4}$ Landcare Research New Zealand Limited, New Zealand
}

Submission: April 07, 2020; Published: April 20, 2020

*Corresponding author: Ian McIvor, Scientist, New Zealand Institute for Plant and Food Research Ltd, Private Bag 11600, Palmerston North 4442, New Zealand

\section{Abstract}

Aim: Populus deltoides $\times$ nigra trees were grown from $3 \mathrm{~m}$-long poles on slopes in three different soil types, pumice, sandy loam and clay loam, to test the hypotheses 1 ) root development differs with soil type, 2) within each soil type, root production decreases as soil bulk density increases.

Methods: Over a three-year period, above-ground growth parameters and root distribution (biomass, length and root diameter size classes) of excavated root systems were measured each year at the end of the growing season, relative to distance from the pole, slope and soil depth.

Results: Soil bulk density near the ground surface was least in pumice $\left(0.65 \mathrm{~g} \mathrm{~cm}^{3}\right)$ and similar for clay loam $\left(1.05 \mathrm{~g} \mathrm{~cm}^{3}\right)$ and sandy loam $1.1 \mathrm{~g}$ $\mathrm{cm}^{3}$ ), respectively. For all three soil types, bulk density increased with depth, at $0.9 \mathrm{~m}$ depth being lowest in pumice soil and highest in sandy loam. In each of the three years of the trial, root length (RL), root mass (RM) and root extension were greatest in the pumice soil and least for trees growing in the sandy loam. Both RL and RM were greater in the clay loam than in the sandy loam but much less than in pumice. The percentage of poplar root mass found in the top $50 \mathrm{~cm}$ of soil was $90-100 \%$ in the sandy loam, 79-94\% in the clayloam and 56-86\% in pumice. Poplar roots reached $1.3 \mathrm{~m}$ depth in the pumice but did not exceed $1.0 \mathrm{~m}$ depth in the other soil types. Mean RM in Year 3 in the pumice soil (948g) was $\sim 13 \mathrm{x}$ that in the sandy loam $(75 \mathrm{~g})$ and $2.3 \mathrm{x}$ that in the clay loam $(421 \mathrm{~g})$. The length of roots $>1 \mathrm{~mm}$ diameter in Year 3 in the pumice $(144.2 \mathrm{~m})$ was $\sim$ $9 \mathrm{x}$ that in the sandy loam $(15.6 \mathrm{~m})$ and $2.3 \mathrm{x}$ that in the clay loam $(63.9 \mathrm{~m})$. RM and RL distribution up slope and downslope varied with soil type, tree and year, and favoured neither slope direction. The mean volume of soil occupied by poplar roots in pumice, clay loam and sandy loam soils in Year 1 was 3.5, 1.3 and $0.6 \mathrm{~m}^{3}$, respectively, and in Year 3 was 20.5, 6.5 and $3.0 \mathrm{~m}^{3}$, respectively.

Conclusion: Root length and RM of Populus deltoides $\times$ nigra trees were negatively correlated with soil bulk density, with root length and mass increasing as bulk density decreased. The results suggest that the rate at which root systems of these poplars will occupy a particular volume of soil and utilise its available water and nutrients will be faster in soils of lower bulk density. This is expected to increase rates of survival during the early years of establishment, particularly in years with drought.

Keywords: Bulk density; Poplar; Pumice; Sandy loam; Clay loam; Root length; Root mass

\section{Introduction}

Erosion is a significant problem on agricultural and forestry land in large parts of the hill country of New Zealand [1]. The most extensive tree-based control measures in pastoral hill country in New Zealand use wide-spaced poplar (Populus spp.) trees to stabilize the soil. Poplars are favoured because of their fast growth rate, extensive root system and ease of establishment among grazing animals [1,2], and are usually established by planting $3 \mathrm{~m}$-long vegetative poles [3]. Pole survival is most at risk in the first two seasons following planting, when the root system is least developed [4]. Previous research showed that cuttings of Populus deltoides $\times$ nigra clones develop high root biomass and long fine roots [5] favouring them for planting as poles. However, there 
was no significant correlation between above-ground biomass and below-ground biomass [5]. Poles which develop considerable above-ground biomass within their first year of growth can die within two years from desiccation, with poor planting technique, poor root development, drought, and narrow pole girth being contributing factors. As for other tree species, root biomass, root length density and specific root length in poplars were found to decrease with depth [5-7] but in these studies the effect of soil physical properties on the root development was not determined. Tree root development can vary depending on the properties of the soil in which they are grown. For example, root densities for a range of Eucalyptus species were lower in poorly structured Vertisol soils compared with other soil types [8]. Similarly, in a water-limited sandy soil xeric Quercus species had greater root production, lower fine-root turnover rates, and thus exhibited a greater risk of dying than did sub-xeric Quercus species [9]. Access to sufficient water is important for the survival of poplar pole cuttings during the first growing season(s) and planting poles to the depth of the water table increased survival rate by a factor of seven [10]. Root growth of poplar is greater in light textured soils compared to clayey soils $[11,12]$, a finding similar to that for pomegranate [13] and other tree species [14]. For twelve tree species growing on European dikes including poplar (P. nigra, P. alba) roots were $20 \%$ more numerous and $65 \%$ larger on the downslope side. The structure of the root system was mainly influenced by soil material and water availability, and far less by tree species [14]. For Salix nigra willow sediment texture was found to be the dominant factor determining above-ground biomass production with coarse-grained sediment (sand) being more conducive to biomass production and survival than finegrained sediments (silt/clay) under similar moisture conditions [15]. A plot study relating soil penetration resistance (using a penetrometer) to tree root development of 5-year-old Italian alder (Alnus cordata Desf.), Japanese larch (Laris kaempferi (Lamb) Carr.) and birch (Betula pendula Roth) and Corsican pine (Pinus nigra var. maritima (Ait.) Melville) [16] found that tree root number and percentage were significantly reduced as soil resistance increased, with $90.7 \%$ of roots occurring in soils where the penetration resistance was $<3 \mathrm{MPa}$. Absolute fine root length decreased with depth for five poplar clones growing in a heavy clay-loam soil varying in bulk density between 1.22 and $1.62 \mathrm{gcm}$ ${ }^{3}$ [5]. Kern et al. noted soil depth to be a significant controlling factor in fine root longevity in Populus deltoides with roots at $30-40 \mathrm{~cm}$ depth having a median life span more than twice that of roots found at $0-10 \mathrm{~cm}$ depth. A review of a large number of studies showed that soil bulk density influences species fineroot morphology, with higher soil bulk density favouring thicker, denser fine roots [17]. Mid-summer drought periods have been associated with high fine root mortality in the top $30 \mathrm{~cm}$ of soil, potentially disrupting the period of fine root elongation intensity [18].

In view of the important influence soil physical properties have on tree root development and survival, this study determined the effect of three soil types of pumice, clay loam and sandy loam, on root growth and development of Populus deltoides $\times$ nigra trees grown from poles, testing the hypotheses that

a) Root development varies with soil type;

b) Within each soil type, root production decreases as soil bulk density increases.

\section{Methods}

\section{Sites}

The investigation was carried out at three trial sites selected on pastoral hillslopes located in areas of predominantly pumice (Otoi), sandy loam (Pahiatua), and clay loam soil types (Bideford) (Figure 1, Table 1). These soil types [19] are widespread throughout the pastoral hill country of the North Island, New Zealand. All sites were on slopes of between $15^{\circ}$ and $20^{\circ}$ and were grazed continuously during the study by both sheep and cattle. Mean annual temperature and rainfall were similar at each site (Table 1), though there was greater variation in monthly rainfall than temperature (Figure 2).

Table 1: Site parameters.

\begin{tabular}{|c|c|c|c|c|c|c|c|c|}
\hline Site & Soil Type & Soil Classification & Location & $\begin{array}{c}\text { Elevation } \\
\text { (m) }\end{array}$ & Aspect & Slope $\left({ }^{\circ}\right)$ & $\begin{array}{l}\text { Mean Rain- } \\
\text { fall } \mathrm{mm} / \mathrm{yr}\end{array}$ & $\begin{array}{l}\text { Mean Annual } \\
\text { Temp }{ }^{\circ} \mathrm{C}\end{array}$ \\
\hline \multirow{2}{*}{ Otoi } & \multirow{2}{*}{ Pumice } & $\begin{array}{l}{ }^{1} \text { Allophanic Orthic Pumice } \\
\text { Soil }\end{array}$ & \multirow{2}{*}{$\begin{array}{l}38^{\circ} 55^{\prime} \mathrm{S}, \\
177^{\circ} 03^{\prime} \mathrm{E}\end{array}$} & \multirow{2}{*}{370} & \multirow{2}{*}{ South-east } & \multirow{2}{*}{$17-25$} & \multirow{2}{*}{1051} & \multirow{2}{*}{14.7} \\
\hline & & ${ }^{2}$ Typic Udivitrand & & & & & & \\
\hline \multirow[t]{2}{*}{ Bideford } & \multirow[t]{2}{*}{ Clay-loam } & $\begin{array}{l}{ }^{1} \text { Argillic Perch-gley Pallic } \\
\text { Soil }\end{array}$ & \multirow{2}{*}{$\begin{array}{l}40^{\circ} 54^{\prime} \mathrm{S} \\
175^{\circ} 48^{\prime} \mathrm{E}\end{array}$} & \multirow[t]{2}{*}{164} & \multirow{2}{*}{$\begin{array}{l}\text { North- } \\
\text { west }\end{array}$} & \multirow[t]{2}{*}{$15-19$} & \multirow[t]{2}{*}{979} & \multirow[t]{2}{*}{12.7} \\
\hline & & ${ }^{2}$ Dystric Eutrochrept & & & & & & \\
\hline \multirow[b]{2}{*}{ Pahiatua } & \multirow[b]{2}{*}{ Sandy-loam } & ${ }^{1}$ Typic Sandy Brown Soil & \multirow[b]{2}{*}{$\begin{array}{c}40^{\circ} 30^{\prime} \mathrm{S}, \\
175^{\circ} 50^{\prime} \mathrm{E}\end{array}$} & \multirow[b]{2}{*}{138} & \multirow[b]{2}{*}{$\begin{array}{l}\text { South- } \\
\text { west }\end{array}$} & \multirow[b]{2}{*}{$16-23$} & \multirow[b]{2}{*}{995} & \multirow[b]{2}{*}{13} \\
\hline & & ${ }^{2}$ Typic Dystrochrept & & & & & & \\
\hline
\end{tabular}

${ }^{1}$ Hewitt (2010), ${ }^{2}$ USDA Soil Taxonomy. 


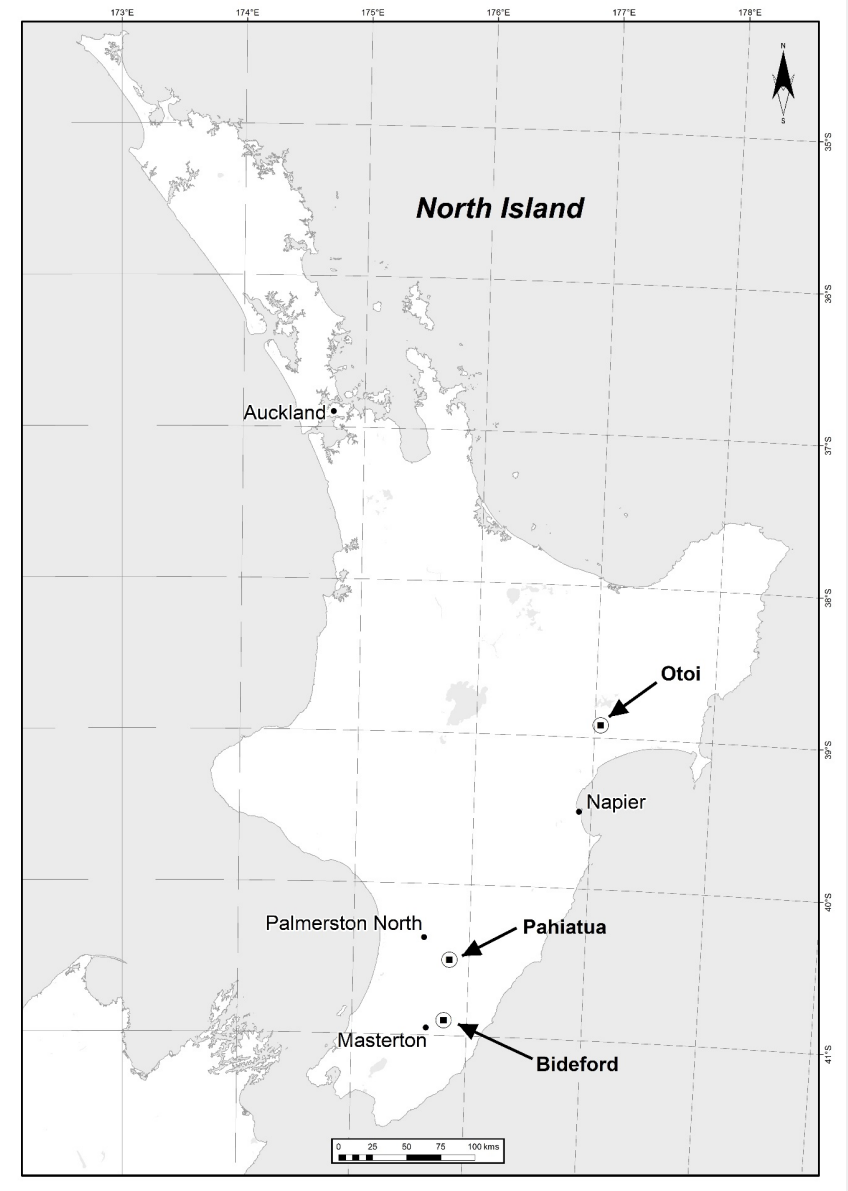

Figure 1: Location of the three trial sites in the North Island, New Zealand.

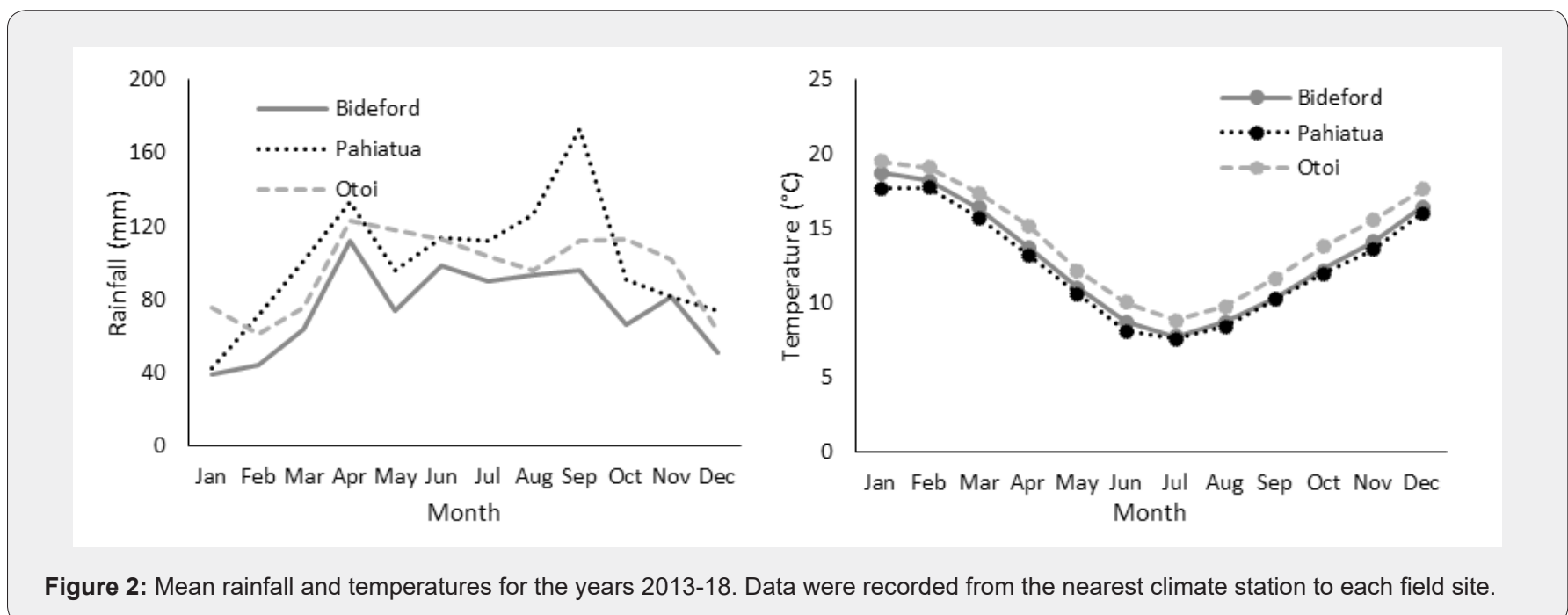

Vegetative cuttings (3m-long poles) of Populus deltoides $x$ nigra with a minimum diameter of $45 \mathrm{~mm}$ at the top of each pole were planted in the winter of 2013. Poles were rammed into the soil to the recommended depth of $0.8 \mathrm{~m}$ [3]. Each pole was enclosed in a $1.6 \mathrm{~m}$ long protective plastic sleeve to prevent stock browsing the bark and killing the pole. A minimum of 25 poles were planted at each site in a grid pattern spaced at least $4 \mathrm{~m}$ apart. 
Poles were not fertilized at planting, though Olsen P levels (Table 2) were low for their respective soil type. Superphosphate is applied to most hill pasture soils to promote pasture production at intervals of one to three years [20]. Mineral deficiency is not considered a limiting factor for tree growth and development in hill pastoral farming systems since no fertilizer is recommended to be applied at or after planting [3].

\section{Above ground measurements}

At the time of planting and again at the end of each growing season (autumn) tree height, collar diameter (measured at the base of the pole), and diameter at the top of the sleeve were measured for all trees at each field site. In each year three trees at each site were randomly selected for excavation. The above ground components of these trees were harvested and separated into branches and pole, their fresh weights measured, and all material later oven dried at $70^{\circ} \mathrm{C}$ for five days, and weighed to the nearest gram.

\section{Root excavation and measurements}

At the end of each growing season the entire root systems of three trees selected at each site were excavated. Root distribution was recorded as being upslope or downslope of the trunk, and roots were separated according to radius (lateral distance) from the trunk and depth from the soil surface. Radius and depth were measured in $0.5 \mathrm{~m}$ intervals. Depth intervals less than $0.5 \mathrm{~m}$ proved too difficult to manage in the field. Where roots were accidently

Table 2: Soil chemical characteristics (0- $0.2 \mathrm{~m}$ depth).

\begin{tabular}{|c|c|c|c|}
\hline Soil Type & Sandy Loam & Clay Loam & Pumice \\
\hline $\mathrm{pH}$ & 5.7 & 5.7 & 5.8 \\
\hline Olsen Phosphorus mg/L & 4 & 7 & 19 \\
\hline Potassium me/100g & 0.14 & 0.26 & 0.36 \\
\hline Calcium me/100g & 3.5 & 5.6 & 7.4 \\
\hline Magnesium me/100g & 0.76 & 2.04 & 0.8 \\
\hline Sulphate Sulphur mg/kg & 3 & 7 & 6 \\
\hline Potentially Available Nitrogen kg/ha & 140 & 142 & 99 \\
\hline Anaerobically Mineralisable N $\mu \mathrm{g} / \mathrm{g}$ & 91 & 107 & 111 \\
\hline Organic Matter \% & 5 & 5.6 & 10.9 \\
\hline
\end{tabular}

\section{Statistics}

Shoot biomass, root biomass, root length, soil volumes occupied were analysed for significant $(\mathrm{p}<0.05)$ differences between soil types and age using ANOVA (Genstat $17^{\text {th }}$ Edition). Because of the unequal replication, terms were tested adjusting for all other effects at the same complexity, e.g. the main effect of soil type was adjusted for the main effect of age. Root and shoot data were log transformed for analysis to stabilize variance. A binomial generalised linear mixed model was applied to the presence or absence of roots in different soil types, ages of trees, depths and distances from tree (the data from radial distance > cut during excavation the cut ends were coded so that the root system could be reassembled in the laboratory. Roots in each of the slope direction $\mathrm{x}$ radius $\mathrm{x}$ depth categories were sorted into root diameter classes of $<1 \mathrm{~mm}, 1<2 \mathrm{~mm}, 2<5 \mathrm{~mm}, 5<10 \mathrm{~mm}, 10<20 \mathrm{~mm}$, and $>20 \mathrm{~mm}$. For material in all root diameter classes except $<1 \mathrm{~mm}$, root length and mass were measured. For roots $<1 \mathrm{~mm}$ diameter mass only was measured, except for clay loam (Year 2) and sandy loam (Year 3) soils where root length was measured also. For each of the excavated root systems, the volumes of soil in each of the slope direction $\mathrm{x}$ radius $\mathrm{x}$ depth categories that contained roots were aggregated to determine the volume of soil occupied by the roots, and mean volumes for each soil type $\mathrm{x}$ year category calculated. Dry biomass of the below-ground section of the pole was included in pole dry mass.

\section{Soil measures}

At each site three soil cores ( $50 \mathrm{~mm} \times 56 \mathrm{~mm}$ ) were collected at depths of $0.05 \mathrm{~m}, 0.2 \mathrm{~m}, 0.35 \mathrm{~m}$, as indicative of bulk density in the upper $0.5 \mathrm{~m}$ of soil depth, and at $0.6 \mathrm{~m}$ and $0.9 \mathrm{~m}$ as indicative of bulk density at soil depth $0.5-1.0 \mathrm{~m}$. In the pumice soil an additional three cores were collected at $1.3 \mathrm{~m}$ depth since roots extended to this depth. Cores were oven-dried at $70^{\circ} \mathrm{C}$ to constant weight and their bulk density determined.

For each soil type 20 soil cores ( $25 \mathrm{~mm}$ diameter) to a depth of $0.2 \mathrm{~m}$ were collected randomly across the site, bulked, thoroughly mixed, and sent to a commercial laboratory to determine its nutrient status (Table 2).
$250 \mathrm{~cm}$ were not analysed; only one tree had roots that extended > $250 \mathrm{~cm}$; the data from $200-250 \mathrm{~cm}$ were taken as 'more than $200 \mathrm{~cm}$ from tree'), allowing for variation between trees, to determine analysis of deviance. To evaluate root diameter class distribution a poisson generalized linear model was used, with fixed effects for soil, age and root size (plus their interactions), a random effect for tree, total mass of roots as an offset and the residual dispersion estimated. Roots with diameter $10-20 \mathrm{~mm}$ and over $20 \mathrm{~mm}$ were combined into one category, as roots thicker than $20 \mathrm{~mm}$ were very rare. Raw data are presented in the tables and figures. 


\section{Results}

\section{Soil chemical properties}

Soil chemical properties were within the range considered typical of these hill soil types in New Zealand.

\section{Bulk density of the soils}

At each depth interval, the pumice soil consistently had a bulk density $50-80 \%$ less than that of the other two soil types (Figure 3). Bulk density of the sandy loam soil was less than that of the clay loam at a depth of $0.2 \mathrm{~m}$ and greater at depths below $0.4 \mathrm{~m}$. The bulk density of the pumice soil increased 3-fold at a depth of $1.3 \mathrm{~m}$ coinciding with a compact layer of fine white volcanic ash.

\section{Tree biomass}

At the time of planting, the mean root collar diameter of poles planted in the pumice soil $(52 \mathrm{~mm})$ was less than that for poles planted in the clay loam $(58 \mathrm{~mm})$ and sandy loam $(64 \mathrm{~mm})$ $(p<0.001)$, but for all three soil types the mean pole diameters measured at the top of the sleeve were not significantly different. By the end of the first growing season root collar diameter and diameter at the top of the sleeve were not significantly different between groups of trees on the three soil types. Thereafter, over a three year period, the increase in root collar diameter varied with soil type ( $p=0.013)$, whereas diameter at the top of the sleeve did not $(p=0.615)$. Trees growing in the pumice soil produced greater shoot (branch) growth in each successive year than did trees growing in either the clay or sandy loam soils (Table 3). Interaction between soil type and tree height was significant $(p<$ 0.001 ) with the greatest increase in tree height recorded for trees growing in the pumice soil and lowest for trees growing in the sandy loam. Interaction between shoot biomass and soil type $(p$ $<0.001$ ) was significant with the greatest increase recorded for trees growing in the pumice soil and lowest for trees growing in the sandy loam.

Table 3: Mean growth parameters for excavated Populus deltoides $\times$ nigra poplar trees aged 1-3 years growing in the three soil types. TOS $=$ top of protective sleeve $(1.6 \mathrm{~m})$.

\begin{tabular}{|c|c|c|c|c|c|c|c|c|}
\hline Soil Type & Year & $\begin{array}{l}\text { Pole DM } \\
\text { (kg) }\end{array}$ & $\begin{array}{l}\text { Shoot DM } \\
\text { (g) }\end{array}$ & $\begin{array}{l}\text { Root DM } \\
\text { (g) }\end{array}$ & $\begin{array}{l}\text { Root length } \\
\text { (m) }\end{array}$ & $\begin{array}{c}\text { Collar Diameter } \\
\text { (mm) }\end{array}$ & $\begin{array}{l}\text { TOS Diameter } \\
\text { (mm) }\end{array}$ & Root: Shoot Ratio \\
\hline \multirow{3}{*}{ Clay Loam } & 1 & 2.22 & 50 & 17.3 & 7.9 & 61 & 43 & 0.32 \\
\hline & 2 & 3.53 & 196 & 74.1 & 14.8 & 63 & 49 & 0.42 \\
\hline & 3 & 3.09 & 763 & 1083 & 63.9 & 62 & 51 & 1.42 \\
\hline \multirow{3}{*}{$\begin{array}{l}\text { Sandy } \\
\text { Loam }\end{array}$} & 1 & 3.08 & 65 & 14.1 & 6.1 & 59 & 51 & 0.21 \\
\hline & 2 & 2.77 & 178 & 45.8 & 12.6 & 62 & 53 & 0.26 \\
\hline & 3 & 2.55 & 373 & 74.6 & 15.6 & 60 & 53 & 0.3 \\
\hline \multirow{3}{*}{ Pumice } & 1 & 2.41 & 89 & 57.8 & 18.8 & 52 & 43 & 0.65 \\
\hline & 2 & 2.83 & 708 & 571 & 69.8 & 58 & 43 & 0.84 \\
\hline & 3 & 4.71 & 4262 & 947.7 & 144.2 & 63 & 61 & 0.25 \\
\hline
\end{tabular}

Both shoot mass and root mass trended significantly upwards with time $(p<0.001)$. The root: shoot ratio of the trees growing in all three soil types was higher in year 2 than in year 1 (Table 3) and was, year-on-year, lowest for trees growing in sandy loam soil and significantly lower than in clay loam. Interaction between soil type and root: shoot ratio was significant $(p=0.043)$ with root: shoot ratio being generally higher for trees growing in pumice soil, but differences in root: shoot ratio between years was not significant.

\section{Root development}

In all three soil types, roots were initiated from the entire length of the buried section of the pole, with the largest proportion of root length and mass emanating from the pole at a depth of 0 $0.5 \mathrm{~m}$. Several roots developed from the bottom of the pole though their extension was limited except in pumice soil. Root length (RL) and root mass (RM) increased significantly each year $(p<0.001)$, and were greater in the pumice than in the clay loam, and greater in the clay loam than the sandy loam (Table 3). After three years of growth RM was $92 \%$ less, and RL $89 \%$ less for trees growing in the sandy loam than for trees growing in pumice. Larger root diameter classes appeared earliest for trees growing in pumice soil (Figure $3 \& 4$ ), followed by those planted in clay loam. Year by year mean fine RM was greatest in pumice and least in sandy loam, with differences between soil types being significant ( $p$ $<0.001$ ). In pumice fine RM (root diameter $<1 \mathrm{~mm}$ ) increased significantly between Year 1 and Year 2; in clay loam it increased significantly between Years 2 and 3; while in sandy loam fine RM did not change significantly over time.

Both root diameter distribution and root spatial distribution differed significantly between soil types (Table 4, Figure 4) (root size $x$ age, $p<0.001$; root size $x$ soil type, $p<0.001$ ).

\section{Soil-root occupancy}

For each soil type, the volume of soil occupied by roots increased from year to year (Figure 6) $(p<0.001)$. Tree roots in pumice occupied more volume than in clay loam, which occupied more volume than in sandy loam. In all years the increase in soil 
volume occupied by roots, was greater in the top $0.5 \mathrm{~m}$ soil depth where soil bulk density was lower, than below this depth (Figure 3 \& 6). In all years the increase in soil volume below $0.5 \mathrm{~m}$ depth occupied by roots was pumice $>$ clay loam $>$ sandy loam. By Year 3 , roots of the trees in pumice had extended to $4 \mathrm{~m}$ from the tree, twice the distance measured for tree roots in clay and sandy loams $(p<0.001)$.
Likewise, roots of trees growing in the pumice were found at a greater depth $(1.3 \mathrm{~m})$ than those growing in sandy and clay loams, and at this depth were found at $>1 \mathrm{~m}$ from the stem. There was however, little root extension into the pumice below $1.3 \mathrm{~m}$ where the bulk density suddenly increased from $0.53 \mathrm{~g} \mathrm{~cm}^{-3}$ to $1.47 \mathrm{~g} \mathrm{~cm}^{-3}$. Soil type had a significant effect on spatial distribution of roots (Table 4), both radially and depth-wise.

Table 4: Analysis of deviance for diameter class distribution of roots, and spatial distribution of roots.

\begin{tabular}{|c|c|c|c|c|}
\hline & Fixed Term & d.f. & Wald/d.f. & chi pr \\
\hline \multirow{7}{*}{ Diameter Class Distribution of Roots } & Age & 2 & 0 & 0.995 \\
\hline & Soil & 2 & 0 & 1 \\
\hline & Age $\mathrm{x}$ Soil & 4 & 2.6 & 0.638 \\
\hline & Root diameter class & 4 & 33.8 & $<.001$ \\
\hline & Root diameter class $\mathrm{x}$ Age & 8 & 8.9 & $<.001$ \\
\hline & Root diameter class $\mathrm{x}$ Soil & 8 & 3.7 & $<.001$ \\
\hline & Root diameter class $\mathrm{x}$ Age $\mathrm{x}$ Soil & 13 & 1 & 0.501 \\
\hline \multirow{14}{*}{ Spatial Distribution of Roots } & Depth & 2 & 22.4 & $<.001$ \\
\hline & Distance from trunk & 7 & 6.6 & $<.001$ \\
\hline & Age & 2 & 10.1 & $<.001$ \\
\hline & Soil & 2 & 19.6 & $<.001$ \\
\hline & Depth x Distance & 9 & 0.2 & 0.991 \\
\hline & Depth x Age & 2 & 0.2 & 0.787 \\
\hline & Depth x Soil & 2 & 0 & 1 \\
\hline & Distance $\mathrm{x}$ Age & 6 & 0.4 & 0.877 \\
\hline & Distance $\mathrm{x}$ Soil & 6 & 0 & 1 \\
\hline & Age x Soil & 4 & 0 & 0.999 \\
\hline & Depth x Distance x Age & 4 & 0 & 1 \\
\hline & Depth x Distance x Soil & 4 & 0 & 1 \\
\hline & Depth x Soil x Age & 4 & 0 & 1 \\
\hline & Distance $\mathrm{x}$ Soil x Age & 7 & 0 & 1 \\
\hline
\end{tabular}

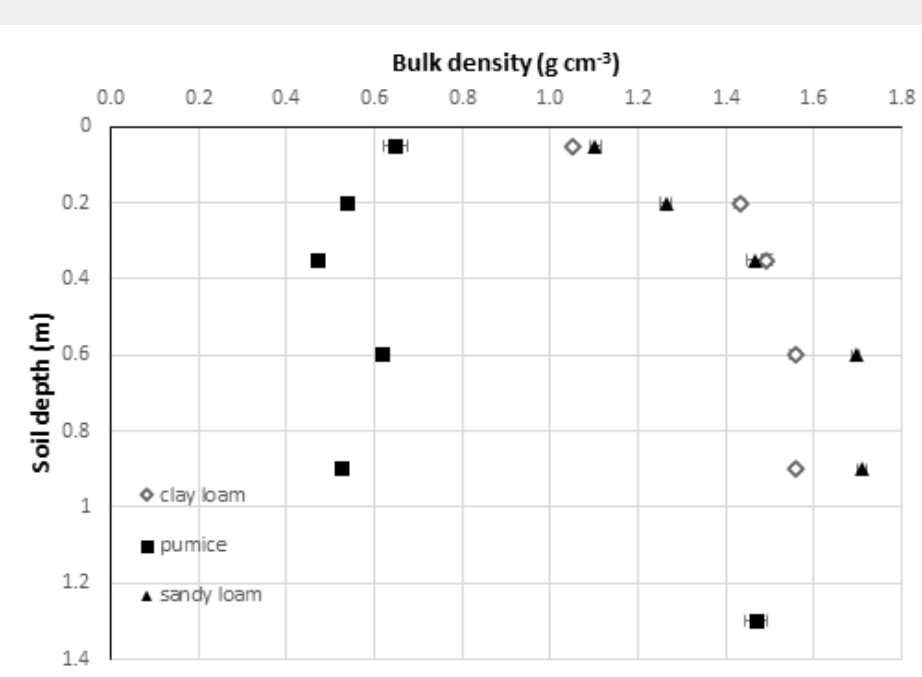

Figure 3: Soil bulk density changes with depth for the three soil types. Error bars = s.e. of means. 


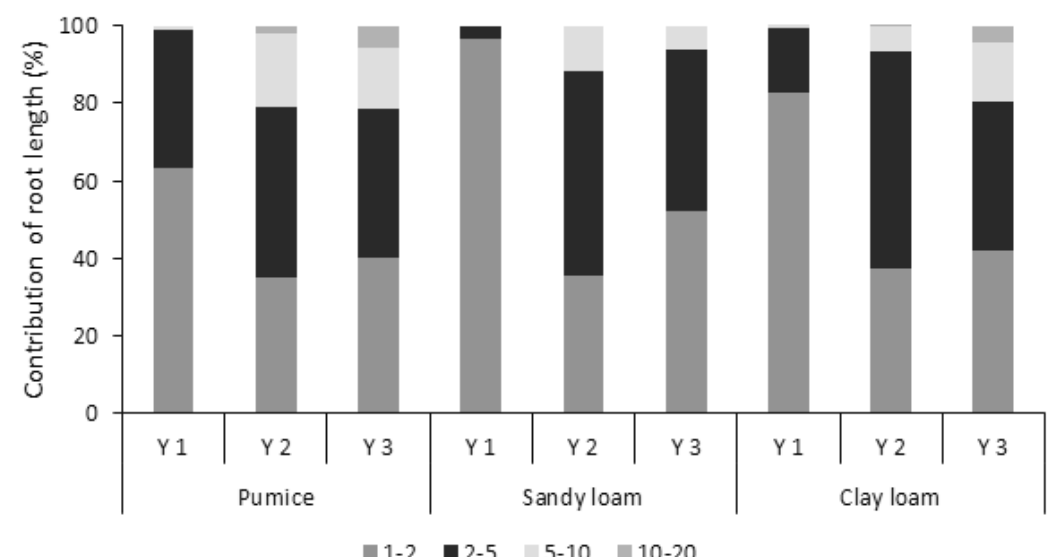

Figure 4: Mean contribution (\%) of root diameter classes $(\mathrm{mm})$ to root length, separated by tree age (Year $(\mathrm{Y}))$ and soil type. Refer to Table 3 for total length data $(m)$.

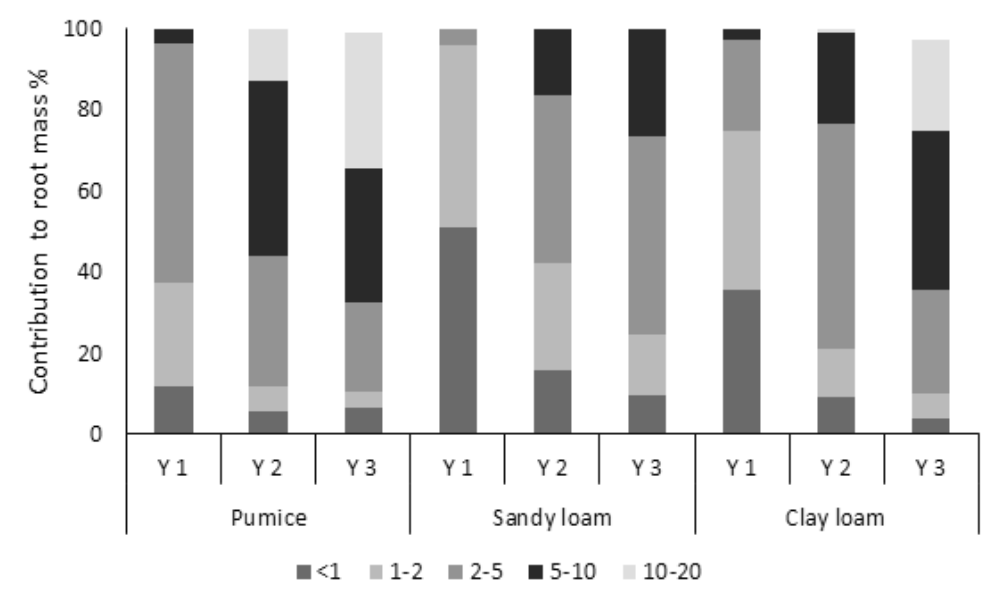

Figure 5: Mean contribution (\%) of root diameter classes $(\mathrm{mm})$ to root mass, separated by tree age (Year (Y)) and soil type. Refer to Table 3 for total mass data $(m)$.

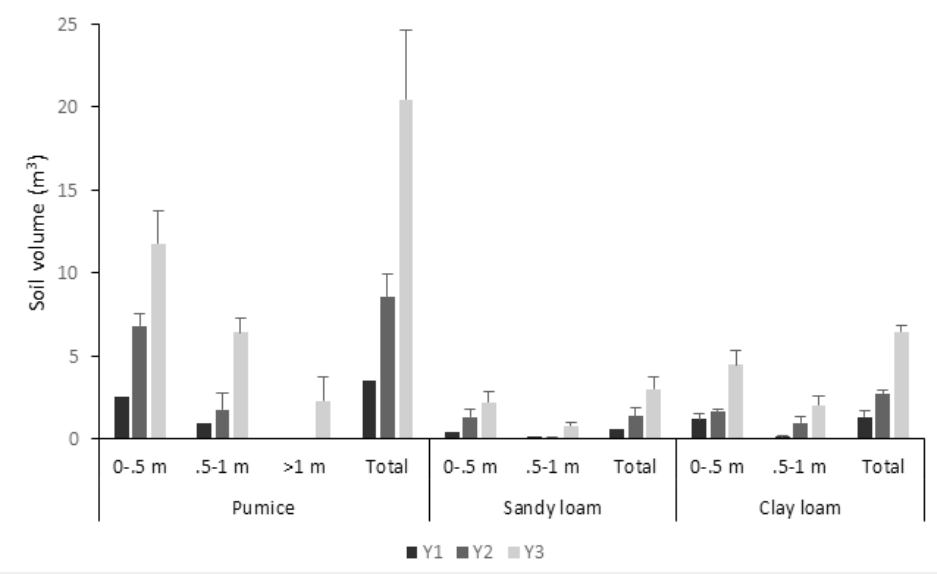

Figure 6: Mean soil volume $(\mathrm{m} 3)$ occupied by roots of poplar trees aged 1-3 years $(\mathrm{Y})$ growing in $0.5 \mathrm{~m}$ depth intervals $($ Total $=$ all depths combined) in three soil types. Error bars $=$ s.e. of the means. 


\section{Root distribution related to slope}

Slope direction did not significantly influence root presence, RM or RL. In the clay and sandy loams, the RM was distributed approximately equally up slope and downslope, slightly favouring the upslope (Table 5), whereas the RM distribution in the pumice soil was in each year greatest in the downslope direction. Trees grown in sandy loam had the highest concentration of RM within the top $0.5 \mathrm{~m}$ of soil (90-100\%), compared with $87-93 \%$ for trees in clay loam, and $56-75 \%$ for trees in pumice. For all three soil types the percentage of RM present below $0.5 \mathrm{~m}$ increased with tree age and as root systems developed. The proportion of RM below $0.5 \mathrm{~m}$ was greater for trees grown in the least dense pumice soil than for trees grown in the denser clay and sandy loam, being $24.6 \%$ in year $1,13.9 \%$ in year 2 and $44 \%$ in year 3 . Likewise, RL distribution was similarly variable between soil type, year, and depth (Table 5).

Table 5: Comparison of \% root distribution upslope and downslope for different years, and depths for poplar trees grown in the different soil types.

\begin{tabular}{|c|c|c|c|c|c|c|}
\hline \multirow[b]{2}{*}{ Soil Type } & \multirow[b]{2}{*}{ Tree Age (year) } & \multirow[b]{2}{*}{ Depth (m) } & \multicolumn{2}{|c|}{ Root Mass \% } & \multicolumn{2}{|c|}{ Root Length \% } \\
\hline & & & Upslope & Downslope & Upslope & Downslope \\
\hline \multirow{6}{*}{ Clay Loam } & \multirow{2}{*}{1} & $0-0.5$ & 52.9 & 40.6 & 33.3 & 57.5 \\
\hline & & $0.5-1.0$ & 1.4 & 5.1 & 4.4 & 4.9 \\
\hline & \multirow{2}{*}{2} & $0-0.5$ & 45 & 33.5 & 44.2 & 31.4 \\
\hline & & $0.5-1.0$ & 12 & 9.6 & 11.6 & 12.7 \\
\hline & \multirow{2}{*}{3} & $0-0.5$ & 46.1 & 41.8 & 34.4 & 47 \\
\hline & & $0.5-1.0$ & 5.4 & 6.7 & 10.9 & 7.7 \\
\hline \multirow{7}{*}{ Pumice } & \multirow{2}{*}{1} & $0-0.5$ & 22.6 & 52.8 & 24.4 & 60.4 \\
\hline & & $0.5-1.0$ & 16 & 8.6 & 10 & 5.2 \\
\hline & \multirow{2}{*}{2} & $0-0.5$ & 36.5 & 49.7 & 39.4 & 51.6 \\
\hline & & $0.5-1.0$ & 7.7 & 6.2 & 4.1 & 5.2 \\
\hline & \multirow{3}{*}{3} & $0-0.5$ & 16.6 & 39.4 & 18.8 & 48.9 \\
\hline & & $0.5-1.0$ & 28 & 12.9 & 16.4 & 11.7 \\
\hline & & $1.0-1.5$ & 2 & 1.1 & 2.5 & 1.7 \\
\hline \multirow{6}{*}{ Sandy Loam } & \multirow{2}{*}{1} & $0-0.5$ & 58.1 & 41.9 & 49.4 & 50.6 \\
\hline & & $0.5-1.0$ & 0 & 0 & 0 & 0 \\
\hline & \multirow{2}{*}{2} & $0-0.5$ & 54.7 & 44.6 & 54.8 & 44.4 \\
\hline & & $0.5-1.0$ & 0.6 & 0 & 0.8 & 0 \\
\hline & \multirow{2}{*}{3} & $0-0.5$ & 59.9 & 30.8 & 57.9 & 30.7 \\
\hline & & $0.5-1.0$ & 8.2 & 1.1 & 10.4 & 1.1 \\
\hline
\end{tabular}

\section{Discussion}

Root growth and development of Populus deltoides $\times$ nigra over the three years of this study was greatest for trees grown in the soil with the lowest bulk density, pumice, and least for trees growing in sandy loam. Root length and RM of trees grown in clay loam were greater than RL and RM of trees in the sandy loam but more closely resembled the root growth of trees in the sandy loam than that of trees grown in the pumice soil. Differences in tree root development in different soil types have been reported previously. Roots of Jatropha curcas seedlings developed more extensively in sandy loam and clay loam soils than in sandy soil, with root length being greatest in the soil with the lowest bulk density (clay loam; 1.26) and least in the soil with the highest bulk density (sand; 1.56) [21]. Similarly, root growth of 4-year-old pomegranate trees was greater in shallow, light textured soils than in deep clayey soils [14] though soil bulk densities were not reported. In this study the pumice soil site experiences $\sim 2^{\circ} \mathrm{C}$ warmer summer temperatures, with annual rainfall being similar for each site. While considering the effect of summer temperature differences, it is considered that the root growth responses measured in here are primarily influenced by the physical properties of the soil, in particular the resistance the soil offers to the penetration of new roots. This finding is in accordance with international research involving a variety of different tree and crop species [12,22-25]. It is also considered that the resistance of the soil measured as its bulk density can be a limiting factor affecting pole root development and survival in years with lower than normal summer rainfall $[22,26]$. 
Soil strength increases with bulk density [22]. Likewise, a decrease in soil water content increases soil strength [22] further resisting root penetration. Roots must exert a growth pressure to overcome the resistance to deformation of the surrounding soil and grow deeper or further into the soil [27]. When experiencing excessive mechanical stress, root apices are able to deflect towards larger macropores [28]. Aggregation of soil particles creates pores for roots to penetrate and soil aggregation is primarily based on the clay content of the soil [29]. It is considered likely that root development of Populus deltoides $\times$ nigra trees in this study, and in particular root length, was restricted by soil physical properties more so in the sandy loam than in clay loam with little restriction in pumice soil. The bulk density of the sandy loam was greater, particularly below $0.4 \mathrm{~m}$ depth, and with low clay content the aggregate formation was the poorest [30] of the three soil types. The percentage of poplar RL and RM found below $0.5 \mathrm{~m}$ depth in Year 3 was 32.3 and 43.0 respectively for pumice, 18.6 and 12.1 respectively for clay loam and 11.5 and 9.8 respectively for sandy loam, being highest for the lower bulk density soil type and lower for the soil types with higher bulk density at that depth. While these observations support the hypothesis that within each soil type root production will be lower in that part of the soil profile with higher bulk density, it is clear that other factors such as nutrient availability influence root development, since there was little resistance to root penetration in pumice soil till $1.3 \mathrm{~m}$ depth, yet the greater root development was still in the upper $0.5 \mathrm{~m}$ of soil. Internationally, root length, root length density, root diameter, and root mass have similarly been observed to decrease with increasing bulk density [7,31].

Higher poplar root densities in light compared to heavy soils have also been related to lower water and nutrient availability $[12,24]$ but in these studies the influence of soil bulk density was not considered since the coarse roots were only investigated to $0.2 \mathrm{~m}$ depth, and fine roots to $0.4 \mathrm{~m}$ depth. Root growth of potted plants of the leguminous tree Faidherbia albida was greater in lighter sandy soil than in clay soil [24], in contrast with the findings of the present study. We suggest that field -based measurements to a greater soil depth better demonstrate the effect of soil bulk density on poplar root development from poles. However, in the case of riverine sediments, which vary widely in particle size, the presence and distribution of Populus nigra roots has been correlated with both moisture and sediment porosity though not depth [32]. Thus, we agreed that where the soil type has considerable porosity (e.g. pumice and river gravels) high root densities can be found at depths well below $0.4 \mathrm{~m}$, and in these instances tree root system structure is likely influenced much more by soil type and water availability than by tree species [14]. Root development was not greater downslope, varying with the soil type. In the pumice at Year 3 there was a greater percentage of RL and RM downslope than upslope, in the sandy loam there was a lesser percentage of RL and RM downslope than upslope, and in the clay loam percentage of RL was greater and RM lesser downslope than upslope. In a study of 12 tree species growing on dike fills [14], the presence of equal or greater distribution of roots in the upslope direction, and at depths below $0.5 \mathrm{~m}$, was interpreted as being an artifact of slope alone with initial root extension being largely horizontal, with roots extending in the upslope direction consequently growing into deeper soil than roots extending in the downslope direction. In support of this view, at Year 3, at depths $>0.5 \mathrm{~m}$ RL was greater upslope in all soil types, and RM was greater upslope in pumice and sandy loam but not in clay loam (Table 5).

A review paper identified a general trend for root:shoot ratios to increase in forests and woodlands as soil texture becomes more coarse, with root:shoot ratios from sand and sandy loam soils significantly greater than those from clay and clay loam soils [33] This was thought to be because water and nutrients are less freely available in coarser soils, though it was acknowledged that roots are easier to collect from coarse soils. However, in grasslands the relationship between root and shoot biomass was highly variable [33], as found in this study. Root:shoot ratios (Table 3) are confounded in this study by water and nutrients being sourced from both the soil and the pole, particularly in year 1 . The root:shoot ratio was generally higher in pumice soil.

Lateral root extension is important for gathering nutrients and water, and to a lesser extent, stabilising the tree $[24,34,35]$. Deep root extension enables the tree to explore a greater volume of soil for water, particularly in periods of low precipitation [32]. Resistance from soil to the penetration of roots reduces their capacity to collect water, even more so where the roots have to generate root diameter at the expense of length [26,27,36,37]. Supply of water and nutrients drives the tissue production above ground. Initially shoot and leaf production is driven by stored water, nutrients and energy from within the pole. Utilisation of the storage water and nutrients can exceed the rate of absorption of water and nutrients by the roots. This is most likely to happen where the barriers created by a high bulk density soil are coupled with reduced soil water.

These research findings suggest that pole survival is likely to be highest in pumice soils, lower in clay loams and lowest in sandy loams, reinforcing the importance of planting poles to the recommended depth of $0.8 \mathrm{~m}$ [3]. Plant available water is likely to be present at this depth during dry spells even though root extension is lower and soil volume explored is smaller than in the soil horizons closer to the surface.

\section{Conclusion}

During the first three years following planting as $3 \mathrm{~m}$ poles, root development (mass and length) of Populus deltoides $\times$ nigra trees growing in either a sandy or clay loam with high soil bulk 
densities was less than for trees planted in pumice soil with low bulk density, supporting the hypothesis that the more compact soils resist root penetration to a greater extent than do less compact soils.

For all three soil types, the greater proportion of poplar root mass and length was confined to the uppermost $0.5 \mathrm{~m}$ of the soil profile where the soil bulk density was lower, and the volume of soil occupied by root was higher. The proportion of root length and mass within this depth interval was equally distributed between the upslope and downslope directions. The proportion of total root biomass and length below $0.5 \mathrm{~m}$ depth was greatest where soil bulk density was lowest and least where it was highest supporting the hypothesis that root penetration resistance increases with depth to a greater extent in loamy soils than in pumice soils.

\section{Acknowledgement}

The research was funded by MBEI SLURI programme, Contract CO2X0813. Project support was provided by Hawke's Bay and Greater Wellington Regional Councils. Hills Laboratories, Hamilton, New Zealand completed the soil analyses.

\section{References}

1. McIvor IR, Douglas GB, Dymond J, Eyles G, Marden M (2011) Pastoral hill slope erosion in New Zealand and the role of poplar and willow trees in its reduction. In 'Soil Erosion Issues in Agriculture' Eds Danilo Godone and Silvia Stanchi, p. 334.

2. Douglas GB, McIvor IR, Manderson AK, Koolaard JP, Todd M, et al. (2013) Reducing shallow landslide occurrence in pastoral hill country using wide-spaced trees. Land Degradation \& Development 24(2): 103-114.

3. Wilkinson AG (1999) Poplars and willows for soil erosion control in New Zealand. Biomass \& Bioenergy 16(4): 263-274.

4. Douglas GB, McIvor IR, Lloyd-West CM (2016) Early root development for field-grown poplar: effects of planting mateial and genotype. New Zealand Journal of Forestry Science 46: 1-14.

5. Al Afas N, Marron N, Zavalloni C, Ceulernansk R (2008) Growth and production of a short-rotation coppice culture of poplar-IV: Fine root characteristics of five poplar clones. Biomass \& Bioenergy 32(6): 494502.

6. Douglas GB, McIvor IR, Potter JF, Foote LG (2010) Root distribution of poplar at varying densities on pastoral hill country. Plant and Soil 333: 147-161.

7. Cui QF, Feng ZP, Yang XT (2017) Distributions of fine and coarse tree roots in a semi-arid mountain region and their relationships with soil properties. Trees-Struct Funct 31: 607-616.

8. Grant JC, Nichols JD, Yao RL, Smith RGB, Brennan PD, et al. (2012) Depth distribution of roots of Eucalyptus dunnii and Corymbia citriodora subsp variegata in different soil conditions. Forest Ecology and Management 269: 249-258.

9. Espeleta JF, West JB, Donovan LA (2009) Tree species fine-root demography parallels habitat specialization across a sandhill soil resource gradient. Ecology 90(7): 1773-1787.

10. Hall JE, Pollock MM, Hoh S, Volk C, Goldsmith J, et al. (2015) Evaluation of dryland riparian restoration with cottonwood and willow using deep-planting and herbivore protection. Ecosphere 6(12): 1-12.
11. McIvor IR, Sloan S, Pigem LR (2014) Genetic and environmental influences on root development in cuttings of selected Salix and Populus clones - a greenhouse experiment. Plant and Soil 377: 25-42.

12. Plante PM, Rivest D, Vezina A, Vanasse A (2014) Root distribution of different mature tree species growing on contrasting textured soils in temperate windbreaks. Plant and Soil 380: 429-439.

13. Marathe RA, Babu KD, Murkute AA, Chaudhary DT (2016) Root distribution pattern of pomegranate in different soil types. Indian Journal of Horticulture 73(4): 588-591.

14. Zanetti C, Vennetier M, Meriaux P, Provansal M (2015) Plasticity of tree root system structure in contrasting soil materials and environmental conditions. Plant and Soil 387: 21-35.

15. Schaff SD, Pezeshki Sr, Shields FD (2003) Effects of soil conditions on survival and growth of black willow cuttings. Environmental Management 31(6): 748-763.

16. Sinnett D, Morgan G, Williams M, Hutchings TR (2008) Soil penetration resistance and tree root development. Soil Use and Management 24(3): 273-280.

17. Freschet GT, Valverde-Barrantes OJ, Tucker CM, Craine JM, McCormack ML, et al. (2017) Climate, soil and plant functional types as drivers of global fine-root trait variation. Journal of Ecology 105(5): 1182-1196.

18. Joslin JD, Wolfe MH, Hanson PJ (2001) Factors controlling the timing of root elongation intensity in a mature upland oak stand. Plant and Soil 228: 201-212.

19. Hewitt AE (2010) New Zealand Soil Classification. ( $3^{\text {rd }}$ edn), Landcare Research Science Series No 1 Lincoln, Manaaki Whenua Press, New Zealand.

20. Schon NL, Mackay AD, Minor MA, Yeates GW, Hedley MJ (2008) Soil fauna in grazed New Zealand hill country pastures at two management intensities. Applied Soil Ecology 40(2): 218-228.

21. Valdes-Rodriguez OA, Sanchez-Sanchez O, Perez-Vazquez A, Caplan JS, Danjon F (2013) Jatropha curcas L. Root Structure and Growth in Diverse Soils. Scientific World Journal.

22. Bengough AG, McKenzie BM, Hallett PD, Valentine TA (2011) Root elongation, water stress, and mechanical impedance: a review of limiting stresses and beneficial root tip traits. Journal of Experimental Botany 62(1): 59-68.

23. Bordoni M, Meisina C, Vercesi A, Bischetti GB, Chiaradia EA, et al. (2016) Quantifying the contribution of grapevine roots to soil mechanical reinforcement in an area susceptible to shallow landslides. Soil \& Tillage Research 163: 195-206.

24. Gachuiri A, Muthuri C, Muriuki JK, Jamnadass RH, Sinclair F (2016) Variations in shoot and root growth of three provenances of Faidherbia albida in clay and sand soil. Journal of Forestry Research 27: 59-66.

25. Vennetier M, Zanetti C, Meriaux P, Mary B (2015) Tree root architecture: new insights from a comprehensive study on dikes. Plant and Soil 387: 81-101.

26. Colombi T, Torres LC, Walter A, Keller T (2018) Feedbacks between soil penetration resistance, root architecture and water uptake limit water accessibility and crop growth - A vicious circle. Science of the Total Environment 626: 1026-1035.

27. Kolb E, Legue V, Bogeat-Triboulot MB (2017) Physical root-soil interactions. Physical Biology 14(6): 065004.

28. Tracy SR, Black CR, Roberts JA, Mooney SJ (2011) Soil compaction: a review of past and present techniques for investigating effects on root growth. Journal of the Science of Food and Agriculture 91(9): 15281537. 
29. Wagner S, Cattle SR, Scholten T (2007) Soil-aggregate formation as influenced by clay content and organic-matter amendment. Journal of Plant Nutrition and Soil Science 170(1): 173-180.

30. Rabot E, Wiesmeier M, Schluter S, Vogel HJ (2018) Soil structure as an indicator of soil functions: A review. Geoderma 314: 122-137.

31. Dal Ferro N, Sartori L, Simonetti G, Berti A, Morari F (2014) Soil macroand microstructure as affected by different tillage systems and their effects on maize root growth. Soil \& Tillage Research 140: 55-65.

32. Holloway JV, Rillig MC, Gurnell AM (2017) Physical environmental controls on riparian root profiles associated with black poplar (Populus nigra L.) along the Tagliamento River, Italy. Earth Surface Processes and Landforms 42(8): 1262-1273.

33. Mokany K, Raison RJ, Prokushkin AS. (2006) Critical analysis of root: shoot ratios in terrestrial biomes. Global Change Biology 12(1): 84-96.

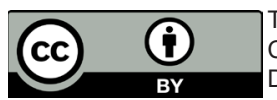

This work is licensed under Creative Commons Attribution 4.0 License

DOI:10.19080/IJESNR.2020.24.556138
34. Cunniff J, Purdy SJ, Barraclough TJP, Castle M, Maddison AL, et al. (2015) High yielding biomass genotypes of willow (Salix spp.) show differences in below ground biomass allocation. Biomass \& Bioenergy 80: $114-127$.

35. Mosseler A, Major JE (2015) Biomass and root stem production of a colony-forming willow (Salix interior) on highly disturbed, low fertility sites. Biomass \& Bioenergy 74: 202-212.

36. Grzesiak MT, Hura T, Grzesiak S, Kaczanowska K, Szczyrek P (2018) Influence of nitrogen deficiency or excess on a root system structure of maize and triticale seedlings grown under low and high soil density. Journal of Agronomy and Crop Science 204(2): 196-208.

37. Herbrich M, Gerke HH, Sommer M (2018) Root development of winter wheat in erosion-affected soils depending on the position in a hummocky ground moraine soil landscape. Journal of Plant Nutrition and Soil Science 181(2): 147-157.

Your next submission with Juniper Publishers will reach you the below assets

- Quality Editorial service

- Swift Peer Review

- Reprints availability

- E-prints Service

- Manuscript Podcast for convenient understanding

- Global attainment for your research

- Manuscript accessibility in different formats

( Pdf, E-pub, Full Text, Audio)

- Unceasing customer service

Track the below URL for one-step submission https://juniperpublishers.com/online-submission.php 